\title{
What Motivates Minority Acquisitions? The Trade-Offs between a Partial Equity Stake and Complete Integration
}

\author{
Paige Parker Ouimet*
}

October 20, 2012

JEL Classification: G32, G34

Keywords: mergers and acquisitions, minority stakes, boundaries of the firm

\footnotetext{
* This paper is part of my doctoral dissertation at the University of Michigan. I am deeply indebted to my dissertation committee members E. Han Kim (Chair), Amy Dittmar, Clemens Sialm, Jagadeesh Sivadasan and Jeffrey Smith for their guidance and advice. I also thank Kenneth Ahern, Sugato Bhattacharyya, Cláudia Custódio, Charles Hadlock, Dalida Kadyrzhanova, Rich Mathews, Adair Morse, Uday Rajan, Enrique Julio Schroth, H. Nejat Seyhun, Anil Shivdasani, Tyler Shumway, Sheridan Titman, Michael Weisbach, two anonymous referees, conference participants at the 2007 European Finance Association, the 2008 Batten conference, the 2009 Western Finance Association meetings, and the ISCTE Mergers \& Acquisitions Conference and seminar participants at Arizona State University, Boston College, Columbia University, Dartmouth College, Duke University, Harvard University, Indiana University, Michigan State University, Rochester University, University of California at Los Angeles, University of California at Irvine, University of Michigan, University of North Carolina, University of Southern California, University of Washington, Vanderbilt University, and Washington University at Saint Louis. I acknowledge funding from the Pre-doctoral Rackham fellowship 2007-2008.

Contact information: Kenan-Flagler Business School; The University of North Carolina at Chapel Hill; Campus Box 3490; McColl Building; Chapel Hill, North Carolina 27599-3490; Paige_Ouimet@unc.edu
} 


\section{What Motivates Minority Acquisitions? The Trade-Offs between a Partial Equity Stake and Complete Integration}

Minority acquisitions, involving less than $50 \%$ of the target, represent a distinct organizational choice. With a minority acquisition, the target can mitigate some of the incentive problems that arise in contractual relationships. Less is known, however, about the trade-off between minority acquisitions and complete integration. We find minority acquisitions are more common when keeping target managerial incentives intact is important and when the target is financially constrained or can benefit from certification. Minority acquisitions are also more likely where the target's valuation is especially uncertain; integrating internal capital markets will be costly; and consolidating earning will lower EPS. 
Minority acquisitions, involving less than $50 \%$ of the target, represent a distinct organizational choice. Allen and Phillips (2000) and Fee, Hadlock, and Thomas (2006) show minority acquisitions can mitigate incomplete contracts and thereby facilitate cooperation between two independent firms. These papers explain why a minority equity stake may be preferred over no integration. However, complete integration through a majority acquisition is also an option. Little is known about the trade-off between minority and majority acquisitions.

In this paper, we study this trade-off, using a sample of 2,166 acquisitions by and of U.S. public firms, announced between 1994 and 2006. This paper finds that the efficient allocation of incentives is an important determinant in the decision to take a minority or majority position in a target firm. A majority acquisition typically precipitates a delisting of the target's stock, thereby decreasing the efficiency of equity-based incentive contracts and reducing target managerial effort ex post. Furthermore, a majority acquisition can reduce the bargaining power of the target's manager, reducing incentives to invest in relationship-specific assets.

While incentive considerations are important in these ownership decisions, other factors, such as target financing needs, also play a role. A minority acquisition can be used to provide financing directly to the target or to certify the target for other outside investors. Minority acquisitions are also more common when gains from a merger are most uncertain. Minority acquisitions can facilitate the flow of information between two firms, allowing the acquirer to better assess the value of the target and expected synergies before committing to purchasing a majority stake. Minority acquisitions may also be preferred if combining internal capital markets is expected to be inefficient, or if consolidating earnings will lower EPS.

Exploring drivers of minority acquisitions can help us better understand how boundaries of the firm are determined. When is it more efficient to organize two firms as independent 
entities linked through an equity stake? Alternatively, when is it more efficient to move armslength transactions within the firm? The answer for any given firm pair will depend on the relative importance of the benefits that can be realized from a minority acquisition as well as on the costs and benefits to acquiring control.

Negative effects on target managerial incentives can be a cost to acquiring control. After a controlling acquisition, the stock of a public target is typically delisted. The stock price of the merged firm will be a diluted signal of the performance of the acquired unit's managers, decreasing the efficiency of any equity-based incentives provided to these managers and potentially increasing agency conflicts at the target firm (Holmstrom and Tirole 1993). In contrast, a minority acquisition is not followed by a delisting. Thus, if preserving existing equitybased managerial incentives is more important than the benefits of acquiring control, firms will be more likely to pursue a minority acquisition.

As predicted, we find firms are more likely to engage in minority acquisitions when the loss of a stock price is expected to lead to a greater dilution to target managerial equity incentives. The potential dilution to target managerial equity incentives is proxied by the relative size of the target and acquiring firms. After a majority acquisition, equity-based incentives provided to the target's manager are likely to be based on the combined firm's stock price. Thus, the dilution to incentives will be greater, the smaller the relative size of the target. We find relatively small public firms are more likely to be targets of minority acquisitions.

Grossman and Hart (1986), Hart and Moore (1990), and Hart (1995) emphasize a related cost to acquiring control. Suppose synergies from a partnership between two firms require at least one firm to invest in assets whose value depends on trades with its partner firm. Incentives to invest in such an asset will be limited given the potential for a hold-up problem: If the partner 
firm demands renegotiation of contracts, the investing firm's bargaining power is limited because the value of the relationship-specific assets depends on continued trade. A majority acquisition can, at least partially, ameliorate incentives. The incentives of the acquirer to invest in relationship-specific assets are increased following a majority acquisition, given the elimination of the hold-up threat from the target firm. However, incentives of the target's owner are lowered, due to a greater risk of expropriation by the acquirer. This can impose a cost to majority acquisitions, depending on the importance of non-contractible relationship-specific investment by the target's owner. Following a minority acquisition, incentives of the target's owner remain unchanged, as no change in control has occurred, and incentives at the acquirer can increase, as shown in Allen and Phillips (2000) and Fee, Hadlock, and Thomas (2006).

We proxy for whether a partnership will require relationship-specific investment by the number of patents held by the partner firm. A firm with more patents will be more unique, and cooperating with this firm is more likely to require the development of relationship-specific assets. We find that minority acquisitions are relatively more common when the acquirer has a large number of patents, consistent with the hypothesis.

While incentive considerations are important, ownership decisions are not driven solely in response to contracting issues. For example, easing target financing constraints is an important determinant in the mode of acquisition. A firm operating in a similar marketplace or having strategic relationships with a constrained firm may be better informed about the constrained firm's investment opportunities and, thus, be able to act as an optimal investor or certify the target in the eyes of other potential investors, as in Fee, Hadlock, and Thomas (2006), Liao (2011) and Hertzel and Smith (1993). We find financially constrained targets are more likely to be associated with a minority acquisition. Moreover, minority acquisitions are more common when 
the target firm can benefit most from certification, as proxied by low analyst coverage and the absence of a pre-existing blockholder.

Minority acquisitions may also be preferred as a means to avoid costs associated with a majority acquisition. Minority acquisitions are more common when the integration of internal capital markets is expected to be especially costly. We proxy for inefficient internal capital markets using the degree of investment opportunity heterogeneity between the two firms, as in Rajan, Servaes, and Zingales (2000). We also document an increased likelihood of a minority acquisition when a consolidating merger is expected to dilute EPS. Finally, we find that as uncertainty regarding the value of the target and related synergies increases, as measured by industry volatility, acquirers exhibit a preference to take a minority acquisition, consistent with a real option hypothesis.

While a majority acquisition may entail costs, some benefits can be fully realized only with a majority stake. For example, a majority acquisition can generate value for shareholders if the consolidation of control facilitates joint production maximization. Production efficiency gains are more likely when both the target and the acquirer operate in the same industry and can share valuable resources. Our data reveal horizontal acquisitions are more likely to involve a majority stake. We also find firms that have excess capital and minimal internal investment needs are more likely to make majority acquisitions, consistent with the notion that agency conflicts at the acquirer may motivate some majority acquisitions.

In sum, minority acquisitions are primarily motivated by the benefits of preserving target managerial incentives, relieving financial constraints at the target, and providing an opportunity for the acquirer to gather more information before committing a majority stake. They also seem to help keep inefficient internal capital markets separate and avoid a dilution to EPS. Majority 
acquisitions, on the other hand, are driven by the ability to maximize joint production and benefits accruing to the acquiring firm's management.

\section{Predictions}

This section details the motivations for minority and majority acquisitions that are explored in this paper. Table 1 summarizes all motivations and the primary predictions associated with each.

\subsection{Target Managerial Incentives}

A majority acquisition can impair target managerial incentives in two different ways. First, the loss of the target's stock price can decrease incentives for the manager. Second, incentives to invest in relationship-specific assets can change following an acquisition.

\subsubsection{Target managerial equity incentives}

A firm consists of agents with divergent interests (Jensen and Meckling, 1976). Managerial effort is valuable to shareholders, but managers are reluctant to provide costly effort unless they are compensated for it. One way to align managerial interests with those of shareholders is to provide managers with equity stakes in the firm. However, equity-based incentives become less efficient once a firm is acquired and its stock is delisted, as an important source of information on managerial performance is lost. This lost signal is costly regardless of whether or not the same target managers continue to work at the merged firm. As long as the merged firm enlists agents with imperfectly observable behavior to manage the acquired firm's assets, a signal of managerial performance is valuable. If the acquired firm's management is 
given new equity stakes in the combined firm, the signal value will be diluted, and the dilution will be greater, the smaller the relative value of the target to the merged firm.

We assume no cost-effective contract exists with which the acquirer can fully offset this dilution to incentives. We assume writing a contract which provides identical incentives with the merged firm's stock price to be too costly. The performance of the acquired unit will be comingled with the performance of the other assets of the acquirer. As such, the merged firm's stock price will be a noisier signal of the acquired firm's managerial performance. Any new contract with identical incentives, but based on this noisier signal, will impose more risk on riskaverse managers. The acquiring firm will have to compensate these managers for the higher risk, thereby making such contracts costly.

Furthermore, Holmstrom and Tirole (1993) show that the presence of a majority stockholder decreases the information contained in the stock price pertaining to managerial performance. Thus, even if the target's stock remains listed following a majority acquisition, valuable information will still be lost. We also assume a tracking stock or a minority share flotation will not adequately replace the lost information. ${ }^{1}$

As such, the target manager's incentives will be diluted following the delisting of the target's stock after a majority acquisition, reducing his incentives to put forth costly effort. This finding suggests that maintaining managerial incentives can be a limit to firm size. Moreover, because the dilution is greater for relatively smaller targets, we predict minority acquisitions will

\footnotetext{
${ }^{1}$ The experience with tracking stocks at General Motors (GM) is illustrative. On acquiring EDS, GM was concerned that changes in the value of EDS would not be adequately reflected in the merged stock price, dominated by the much larger GM. Significantly, many EDS employees received equity-based incentives, leading to the issuance of the EDS tracking stock in October 1984. However, the EDS tracking stock was eventually considered unsatisfactory. Disagreements over transfer prices between EDS and the rest of GM highlighted the potential for GM to manipulate the value of the EDS shares and caused the EDS tracking stock to reflect factors other than the performance of the EDS division (see Holmstrom and Tirole 1989). D'Souza and Jacob (2000) make a similar point by finding a 30\% correlation in returns between a tracking stock and its parent. This correlation with the parent firm is three times the magnitude found when using similar, but independent, firms.
} 
be more common for relatively smaller targets. We predict, furthermore, that this dilution will be more costly when alternative signals of managerial performance, such as accounting measures, are less informative.

\subsubsection{Relationship-specific investment incentives}

Incentive problems can arise when two independent firms act cooperatively as part of an implicit or explicit long-term agreement. For the partnership to be successful, one or both firms may have to invest in assets which are specific to the relationship. This creates a hold-up problem, as pointed out by Klein, Crawford, and Alchian (1978). Suppose synergies from the partnership require firm A to invest in an asset whose value depends on trades with firm B. After the relationship-specific investment has been made, firm B may attempt to restructure the terms

of the contract, knowing the investment has little or no value outside of their partnership. Firm A will anticipate this potential hold-up and, thereby, have limited incentives to develop relationship-specific assets.

One solution is for firm A to acquire majority ownership of firm B. With integrated ownership, the threat of opportunistic re-negotiation by firm B is removed, improving firm A's incentives to make the investment (Grossman and Hart 1986; Hart and Moore 1990; and Hart 1995). However, even with integrated ownership, full synergies may not be attained. The acquisition of control over the target's resources can improve the acquirer's incentives to invest, but the target's owner/manager's incentives to improve returns on relationship-specific assets may be lowered following the acquisition. Before the majority control acquisition, the target's owner/manager would directly benefit from any value gain at the target though his equity stake. After the majority control acquisition, the target's owner/manager will expect to benefit less 
from any returns on relationship-specific investments. This can impose a cost to majority acquisitions if non-contractible investments by the target's owner/manager are necessary to achieve value gains.

Minority acquisitions do not have the same negative impact on the target's owner/manager's incentives, since control is not transferred. Minority acquisitions can also provide the acquirer with incentives to invest in relationship-specific investments. Allen and Phillips (2000) and Fee, Hadlock, and Thomas (2006) document evidence indicating that an equity stake can better align the incentives of the acquirer with those of the target. ${ }^{2}$ Thus, we hypothesize that an acquiring firm will take a minority stake when concerned with a holdup problem by its partner and, simultaneously, wants to retain the incentives of the manager/owners at the partner firm to make relationship-specific investments.

To test this hypothesis, we use the number of patents held by the partner firm as a proxy for the importance of relationship-specific investments. Patents, by definition, reflect unique innovations. A firm with more patents will be more unique, and any partnership it has is likely to require unique, relationship-specific investments which are less likely to be transferable outside of the relationship. We predict minority acquisitions will be relatively more common when the acquirer has a large number of patents. Moreover, as the hypothesis depends on the assumption that the target manager is also an owner, we expect the relationship between acquirer patents and minority acquisitions to only hold when the target manager has a significant equity stake, measured as ownership of $1 \%$ or more of the firm.

\footnotetext{
${ }^{2}$ Aghion and Tirole (1994) dispute this conclusion. They find that future prices at which the partners trade goods or services will adjust to net out any profits or losses associated with an equity stake. However, Dasgupta and Tao (2000) show equity ownership can encourage relationship-specific investment if third party firms are potentially interested in purchasing assets developed as part of the relationship. Filson and Morales (2006) find, further, that equity stakes can affect incentives for relationship-specific investment through a monitoring and information channel. A minority acquisition will facilitate information flow, thereby allowing the acquirer to commit future resources toward the partnership under less uncertainty.
} 


\subsection{Acquirer financing constraints}

Costly external financing makes it comparatively more expensive for the acquirer to purchase a majority stake of a relatively larger target. Thus, financing constraints on the part of the acquirer yield a prediction that minority acquisitions should be more likely when the target is large relative to the acquirer. This prediction runs counter to the target managerial equity incentives hypothesis.

\subsection{Target financing}

Fee, Hadlock, and Thomas (2006) and Liao (2011) show that non-financial corporations can be optimal providers of financing via minority acquisitions. An acquiring firm may be willing to provide capital at a lower cost because it is more informed about the target, as compared to other providers of outside capital, or if it anticipates non-financial benefits from its investment. As such, we predict a minority acquisition is more likely when the target is financially constrained. We follow Fee, Hadlock, and Thomas (2006) and proxy for financial constraints by whether the target has a negative free cash flow.

An informed acquirer's minority acquisition may also certify investment worthiness of the target to other investors, as in Hertzel and Smith (1993). Such certification will be most valuable for target firms that have not been certified previously by another investor or that are more opaque to investors, such as those with low analyst coverage. Thus, we predict relatively more minority acquisitions at firms having no pre-existing blockholders and few analysts.

\subsection{Real options}


Alternatively, a minority acquisition may be part of a real options strategy: Acquire a minority position to access greater information about the target firm and better assess the potential for a majority acquisition. This approach differs from a traditional toehold, as the motivation is based on learning, rather than on buying a portion of the target before share prices rise in reflection of the takeover premium. Consistent with this conjecture, Higgins and Rodriquez (2006) find that acquirers who had previously participated in a strategic alliance with their target firm (where such alliances are often accompanied by equity stakes) realize higher returns at the announcement of majority acquisitions.

Because uncertainty enhances the value of real options, this real option motivation is more likely when greater uncertainty exists regarding the target. We proxy for uncertainty using industry stock market volatility. The hypothesis predicts that higher industry volatility will be associated with relatively more minority acquisitions.

\subsection{Internal capital markets}

A majority acquisition will lead to a larger, and potentially less efficient, internal capital market at the acquirer. Rajan, Servaes, and Zingales (2000) argue internal capital markets are less efficient, the greater the investment opportunity heterogeneity between divisions. We assume the acquirer is aware of these costs but is either unable to bond against anticipated inefficiencies, or that doing so is too expensive within the structure of a majority acquisition. The only way for firms to avoid such costs is to instead pursue a minority acquisition. Thus, we predict relatively more minority acquisitions when greater investment opportunity heterogeneity exists between the target and acquirer. We proxy for investment opportunity heterogeneity using 
differences in growth prospects, as measured by the acquirer and the target industry median market to book ratio.

\subsection{Earnings dilution}

Firms may be reluctant to take a majority stake which leads to an earnings consolidation that will lower EPS at the acquirer. We use the most recent earnings as a proxy for future earnings and estimate whether a consolidating merger will lower EPS. We predict minority acquisitions will be more common when a consolidating merger will dilute EPS

\subsection{Benefits to majority control}

Although minority acquisitions are associated with a number of benefits, they do not provide complete control with which the acquirer could potentially realize additional efficiency gains from combining the target's resources with its own. Achieving such efficiency gains may drive majority acquisitions. Further, majority acquisitions may be preferred by the acquiring manager to fulfill an empire building objective.

Control over assets may be necessary for achieving certain acquisition synergies. When two firms merge, they cease to act as separate units, allowing for the maximization of a single joint production function. Joint maximization can lead to an increase in production efficiency or an increase in market power. We assume production efficiency gains from joint maximization are expected to be greatest when the target and acquirer operate in same industry, i.e., horizontal mergers (Maksimovic and Phillips 2001).

A merger can also increase market power over customers, as shown in Kim and Singal (1993), or suppliers, as shown in Fee and Thomas (2004) and Shahrur (2005). We assume a 
majority acquisition will have a greater effect on market power. Minority acquisitions are unlikely to affect market power because of the limits to coordinated actions in the absence of control. The U.S. government appears to agree. Gilo (2000) finds that regulators have been less inclined to challenge minority stakes on anti-trust grounds, instead viewing these investments as passive and lower threats to fair competition. We proxy for the benefits to control associated with market power, using the acquirer industry Herfindahl index. When joint maximization is most valuable, we predict majority acquisitions will be more common.

Finally, to the extent that shareholder and managerial incentives are misaligned, the CEO may pursue an acquisition for personal gains. For example, managers may prefer majority acquisitions to increase firm size, which is shown to be highly correlated with their compensation (Murphy 1985, and Gabaix and Landier 2008.) Following the approach of Lang, Stulz, and Walkling (1991), we proxy for agency-motivated acquisitions by identifying acquiring firms with both low growth options and high free cash flow.

\section{Data and sample selection}

\subsection{Identifying minority and majority acquisitions}

The sample covers acquisitions announced between 1994 and 2006 involving listed U.S. acquirers and targets. Thomson's Security Database Clearinghouse (SDC) identifies 3,643 mergers and acquisitions over this period that can be matched to the Compustat and CRSP databases. Deals are classified as minority acquisitions if less than $50 \%$ is acquired, and as majority acquisitions if greater than or equal to $50 \%$ is acquired. To avoid a possible sample selection bias, we include withdrawn or unsuccessful bids. When the intended acquisition is greater than $50 \%$ but the bid ends up with less than $50 \%$, it is coded as a majority acquisition. 
We drop 399 observations, either because inadequate information exists to determine if the deal was for a minority or majority stake, or because the acquirer already had a majority stake, leaving 2,836 majority and 408 minority acquisitions.

We apply the following screens to the sample. First, observations are dropped if multiple firms acquire the same target on the same day (involving 2 majority and 11 minority acquisitions). The acquiring firms in these cases are often related through cross-holdings, making it difficult to identify if control was attained. Second, some firms take multiple days to complete an acquisition. To avoid double counting these staged acquisitions, we include only the later acquisition, counting the final equity stake, if acquisitions involving the same target and acquirer occur within 20 trading days (dropping 15 majority and 42 minority acquisitions). Finally, we

follow the literature and exclude acquirers whose acquisitions are highly regulated, dropping 906 majority and 100 minority acquisitions by financial firms (SIC codes 6000-6999) and utilities (SIC codes 4911-4931). These screens yield a final sample of 1,913 majority and 255 minority acquisitions involving 1,191 and 177 unique acquirers in the majority and minority samples, respectively.

\subsection{Characteristics of minority and majority acquisitions}

Table 2 presents summary statistics for both minority and majority acquisitions. All accounting data (summarized in this Table or used in later tests) are from the most recent annual report, which strictly predates the acquisition announcement. Minority acquisitions tend to involve the transfer of a sizable portion of the target firm, with a mean purchase of $12 \%$. More than two thirds of the minority acquisitions in the sample involve an ownership stake of between $5 \%$ and $25 \%$. Small equity stakes of less than $5 \%$ of the target are rare, representing just $16 \%$ of 
the minority acquisition sample. The most common majority acquisition involves an ownership stake of $90 \%$ or more. The acquirer purchases less than $90 \%$ of the target in only $3 \%$ of the majority acquisition sample.

Firms making minority acquisitions are larger, on average, than those making majority acquisitions. The average market capitalizations (in 2006 \$) of minority and majority acquirers are $\$ 42.6 \mathrm{~B}$ and $\$ 14.8 \mathrm{~B}$, respectively. Both types of acquirers tend to be profitable the year before the acquisition announcement. Although targets of minority acquisitions are larger than targets of majority acquisitions, on average, this difference is not statistically significant. Targets of minority acquisitions tend to have higher research and development expenses and lower earnings than do targets of majority acquisitions. Relative size is estimated as the ratio of the target market capitalization to combined market capitalizations, evaluated 28 calendar days before the acquisition announcement. Minority acquisitions are associated with smaller mean and median relative size ratios than are majority acquisitions.

Both types of acquisitions are associated with positive announcement returns. Using the Bradley, Desai, and Kim (1988) value-weighted approach, we measure joint announcement returns over a three-day window surrounding the announcement. Average joint announcement returns for minority and majority acquisitions are $0.32 \%$ and $0.46 \%$, respectively. These joint returns are statistically different from zero at the 5\% level. Although no statistical difference in joint returns exists between the two samples, a difference in the division of these gains is measurable. Acquirers gain more, and targets gain less, with minority, as compared to majority, acquisitions. 
Table 3 reports the distribution of acquirer and target industries for both minority and majority acquisitions. The targets and acquirers in both samples operate in a diverse crosssectional distribution of industries.

\section{Empirical results}

This section presents an empirical analysis of the choice between minority and majority acquisitions. Tables 4 through 7 present logit regression estimation results. The dependent variable assumes a value of 1 if the acquisition is for a minority stake and a value of 0 if for majority control. Table 4 considers the role of preserving target managerial incentives in the acquisition decision and Table 5 explores other benefits to a minority acquisition. Table 6 investigates benefits to a majority acquisition. After each motivation is considered separately, all motivations are tested together in the final column of Table 6. Table 7 provides additional robustness tests of the target managerial incentive hypothesis. Standard errors are robust and account for clustering of the error term at the firm level.

\subsection{Maintaining target managerial incentives}

Table 4 explores the relationship between target managerial incentives and the choice between a minority and majority acquisition. We first look at the role of preserving equity-based incentives. Second, we consider the importance of maintaining relationship relationship-specific investment by the target. 


\subsubsection{Preserving equity-based incentives}

As reported in column 1 of Table 4, the coefficient on relative size is negative and statistically significant, indicating minority acquisitions are relatively more common when the target is smaller relative to the acquirer. To isolate whether this result is driven by the size of the acquirer or the target or both, in column 2, target and acquirer market capitalizations are included separately. The sizes of both firms are significant predictors of the acquisition decision. Smaller targets and larger acquirers are more likely to participate in minority acquisitions. These results are consistent with a prediction of the target managerial incentives hypothesis and inconsistent with a prediction of the acquirer financing constraints hypothesis.

However, evidence in support of acquirer financing constraints may be obscured in the full sample if only a subset of acquiring firms is constrained. Thus, we separate acquiring firms most likely to be financially constrained, using an indicator variable, Acquirer FINCON. We identify financially constrained acquirers as firms in the youngest age quartile (9 years or younger), after excluding firms with recent IPOs (within the last 5 years). ${ }^{3}$ Hadlock and Pierce (2010) find that younger firms are more likely to be financially constrained. Firms with recent IPOs are excluded out of concern that firms may time their IPOs to fund anticipated M\&A transactions. Kim and Weisbach (2008) find that equity offerings are often motivated as a means to raise capital for future projects. Celikyurt, Sevilir, and Shivdasani (2010) document greater M\&A activity in the 5 years following an IPO.

Column 3 reports a negative correlation between relative size and minority acquisitions for non-constrained acquiring firms. However, for financially constrained acquiring firms, this correlation is significantly weaker, consistent with our prediction that constrained acquirers

\footnotetext{
${ }^{3}$ Founding dates are from the Field-Ritter dataset, as used in Field and Karpoff (2002) and Loughran and Ritter (2004). IPO dates are from Compustat. Firms with missing data on founding dates are assumed to be older and, thus, financially unconstrained. Missing IPO dates are replaced with the first year the firm appeared in CRSP.
} 
exhibit a stronger preference for purchasing minority stakes of relatively large targets than do non-constrained acquirers.

Column 4 explores the second prediction of the target managerial incentive hypothesis: Relative size should be a weaker predictor of the acquisition decision when accounting variables are more informative of managerial performance. We conjecture that when accounting numbers are more informative of managerial performance, firms rely more on accounting based information to determine CEO pay. As such, we proxy for the relative informativeness of accounting variables by the sensitivity of CEO pay to accounting earnings.

CEO accounting pay sensitivity is estimated at the (3-digit SIC) industry level as a result of data limitations. Data on CEO pay comes from Execucomp. Only $15 \%$ of the individual target firms, but $97 \%$ of the target firms' industries, are covered by the Execucomp database. Within each industry-matched group, one year change in total compensation is regressed on operating performance with year fixed effects. CEO accounting pay sensitivity high is an indicator variable which takes a value of 1 if the correlation between change in CEO compensation and accounting performance is above the sample median among firms in the target's industry.

Column 4 reports a positive and significant coefficient on the interaction of CEO accounting pay sensitivity high and relative size, indicating that the correlation between relative size and the mode of acquisition is weaker in industries where accounting information is more reliable, as proxied by high CEO accounting pay sensitivity. This result is consistent with the target managerial incentive hypothesis. Additional robustness tests of this hypothesis are considered in Table 7. 


\subsubsection{Preserving incentives for relationship-specific investment}

Columns 5 through 7 consider the importance of relationship-specific investment in the acquisition decision. Patent data is from the 2006 NBER Patent Citation database. We count all patents for a given firm if the patent application date precedes the date of the acquisition announcement by no more than 15 years. Patents more than 15 years old are excluded as these patents are close to losing their protection and no longer represent unique firm technology. The indicator variable, high patent acquirer, assumes a value of 1 if the acquirer's patent count is in the top quartile of the sample distribution (10 or more patents). The indicator variable, high patent target, assumes a value of 1 if the target's patent count is in the top $80^{\text {th }}$ percentile $(1$ or more patent). ${ }^{4}$

Column 5 shows a positive and statistically significant relation between a high patent acquirer and the likelihood of a minority acquisition. These results are consistent with the relationship-specific investment hypothesis. Cooperating with a high patent acquirer is more likely to require relationship-specific investment from the target, incentives for which may be harmed by a majority acquisition. Column 5 also shows a negative but statically insignificant relation between high patent target and the likelihood of a minority acquisition. The insignificant finding is consistent with the argument that both minority and majority acquisitions increase the incentives of the acquirer to invest in relationship-specific assets. However, given the more modest standard deviation in patent counts among the target firms in our sample, as compared to the sample of acquiring firm, we cannot exclude the possibility that the lack of significance is driven by a power issue. ${ }^{5}$

\footnotetext{
${ }_{5}^{4}$ For the sample of target firms, the $75^{\text {th }}$ percentile had 0 patents.

${ }^{5}$ One explanation for the more modest variation in patent counts in the target sample assumes high patent firms face greater investment distortion in the absence of integration. In which case, Grossman and Hart (1986) predicts these firms are more likely to be acquirers, resulting in few high patent target firms in the sample.
} 
Column 6 explores two additional predictions of the relationship-specific investment hypothesis. Critical to the hypothesis is the assumption that the manager of the target is also an owner. As such, the relationship between acquirer patents and minority acquisitions should only hold if the target manager has significant equity ownership. We identify target managers who are also owners when they have beneficial ownership of $1 \%$ or more of the target, as reported in the most recent public filing which strictly predates the acquisition announcement. ${ }^{6}$ Second, the more innovative the patent, the stronger should be the relation between acquirer patents and minority acquisitions. We assume single segment firms engage in more novel innovation, as in Seru (2011). We identify single segment firms as those firms that do not report sales in multiple business segments in the Compustat segment files.

As predicted, the relation between acquirer patents and the likelihood of a minority acquisition is weaker when the target manager has low ownership. Furthermore, the relation between acquirer patents and the likelihood of a minority acquisition is stronger for single segment acquirers. As larger firms tend to have more patents, Column 7 shows the relation between a high patent acquirer and minority acquisitions is robust to controls for firm size, after excluding observations where the acquirer operates in multiple segments and the target manager has low equity ownership.

These results suggest a limit to firm size associated with maintaining managerial incentives. These costs must be balanced against anticipated benefits from integrating business activities when determining optimal firm boundaries. We directly test this conclusion in Table 6 and find that preserving target managerial incentives continues to play an important role in the

\footnotetext{
${ }^{6}$ We use a cut-off of $1 \%$, as the SEC does not require detailed reporting of ownership below $1 \%$. We identify the target manager as the CEO of the firm. If the firm does not report a CEO, we use the holdings of the firm's President.
} 
acquisition decision after controlling for expected benefits from integration as well as other determinants of minority acquisitions.

\subsection{Other drivers of minority acquisitions}

Table 5 explores these other determinants of minority acquisitions. A minority acquisition can be used to provide financing directly to the target or to certify the target for other investors. Furthermore, a minority acquisition can facilitate information transfer, allowing the acquirer to better assess the desirability of a majority acquisition. Finally, we consider potential real or perceived disadvantages of a merger that can be avoided by taking a minority stake, such as an inefficient combination of internal capital markets or a lower EPS when consolidating earnings.

\subsubsection{The target financing hypothesis}

Column 1 of Table 5 investigates whether minority acquisitions are used to provide targets with direct financing. The variable, target FCF negative, assumes a value of 1 if the firm has negative free cash flow. Free cash flow is calculated as the firm's income before extraordinary items, plus depreciation and amortization, minus capital expenditures. As predicted, a minority acquisition is more likely when the target has negative free cash flow, consistent with Fee, Hadlock, and Thomas (2006) and Liao (2011).

In column 2, we consider an alternative measure of financial constraints at the target, target FINCON. Target FINCON assumes a value of 1 if the target's founding date is in the lowest sample quartile and at least 5 years have passed since the firm's IPO. This measure is equivalent to the definition used to determine acquirer FINCON. With this alternate proxy, we 
continue to find a positive correlation between target financial constraints and minority acquisitions.

Alternatively, acquirers may alleviate target financial constraints by certifying the target for other outside investors, an act that will be most valuable if the target firm has no pre-existing monitors, as proxied by $5 \%$ blockholders. We identify blockholders using institutional investor holdings, as reported in $13 \mathrm{~F}$ filings, as of the quarter which strictly precedes the acquisition announcement. Column 3 reports a positive and significant relation between the absence of a 5\% blockholder and a minority acquisition. This result is consistent with a certification hypothesis. However, this result is also consistent with a monitoring hypothesis. ${ }^{7}$ Shleifer and Vishny (1986) and Wruck (1989) show that an acquirer has incentives to monitor a target following a minority acquisition. Expected gains associated with new monitoring will be greater when the target firm has no pre-existing monitors.

Column 4 attempts to distinguish between these two hypotheses. Certification will be most valuable when high asymmetric information exists at the target. We proxy for high asymmetric information with a dummy variable, analyst coverage low, which takes a value of 1 if the target has analyst coverage in the lowest sample quartile. Kang and Kim (2008) show that monitoring will be less costly if the target and acquirer are located in the same state. Thus, if the monitoring hypothesis explains the blockholder result, we predict a stronger relation between no blockholders and minority acquisitions when the target and acquirer share a state. As reported in column 4 , the positive relation between the absence of a blockholder and minority acquisitions is stronger at firms with limited analyst coverage. We find an insignificant interaction between

\footnotetext{
${ }^{7}$ These results could also be consistent with a tunneling hypothesis, as in Kim (2012). In an internet appendix available online, we test the tunneling hypothesis and find no supportive evidence.
} 
sharing the same state and the absence of a blockholder. These findings buttress the certification hypothesis.

These results emphasize that ownership patterns are not entirely explained as a means to optimally provide incentives. Partial ownership stakes can also be used to resolve asymmetric information, which may otherwise limit financing at the target.

\subsubsection{Real option hypothesis}

The real option approach to an acquisition will be most valuable when greater uncertainty exists as to the value of the target and associated synergies. We proxy for uncertainty with the target's average industry (3-digit SIC) stock market volatility. Volatility is measured using monthly returns in the year prior to the acquisition announcement. Column 5 shows that greater industry volatility predicts a minority acquisition, supporting the real option hypothesis.

\subsubsection{The internal capital market hypothesis}

Column 6 explores a prediction regarding internal capital markets. We assume combining internal capital markets will be less efficient when the merged firm has more heterogeneous investment options, as in Rajan, Servaes, and Zingales (2000). Divergence in investment opportunities is estimated by the variable, MB difference, and calculated as the absolute value of the difference between the industry median market to book ratios for the acquirer and target, normalized by the ratio of the acquirer. We find that our proxy of the costs to integrating internal capital markets is positively correlated with minority acquisitions. 


\subsubsection{The earnings dilution hypothesis}

Firms may be reluctant to take a majority stake which leads to consolidated earnings, if a consolidation will lower EPS at the acquirer. EPS dilutive is an indicator variable which takes a value of 1 if a consolidating acquisition is expected to lower EPS at the acquirer. The expected change in EPS is estimated as the difference between the most recent EPS at the acquirer and an estimated post-merger EPS for the consolidated firm. The post-merger consolidated EPS is calculated as the sum of the most recent earnings at both firms divided by shares outstanding at the consolidated firm. Shares outstanding at the consolidated firm are estimated as the sum of the acquirer's existing shares plus new shares expected to be created following the merger. The number of new shares is estimated by dividing the target market capitalization by the acquirer share price. Column 7 reports a positive relation between a dilution to EPS and minority acquisitions, consistent with the earnings dilution hypothesis.

\subsubsection{Other drivers of minority acquisitions}

Column 8 includes proxies for the target financing, real option, internal capital markets, and earnings dilution hypotheses as well as controls for firm size. All results are robust.

\subsection{Benefits to majority control}

This section investigates whether benefits that can best be achieved with a majority acquisition can predict the mode of acquisition. We consider benefits arising from control over target assets as well as benefits which accrue specifically to acquirer managers. 


\subsubsection{Benefits to control over assets}

To evaluate benefits to control over assets, we test the relation between acquisition decisions and proxies for benefits associated with production efficiencies (same industry) or increased market power (acquirer industry Herfindahl index). Same industry is an indicator variable which takes a value of 1 if the target and acquirer share an industry. Herfindahl index is estimated for the acquirer's industry, prior to the acquisition announcement. Both measures are estimated using 3-digit SIC codes.

Table 6 shows the relation between benefits to control and the mode of acquisition. Column 1 documents that same industry is a significant predictor of majority acquisitions, consistent with the hypothesis that greater expected production efficiency gains increase the likelihood of pursuing a majority acquisition. Column 2 relates the acquirer industry Herfindahl index to the choice between a minority and majority acquisition and does not show a significant relation. The lack of a significant finding may indicate that increasing market power is not a main driver in this decision or may reflect the noise in our proxy. Possible interventions by regulators may discourage market power motivated acquisition bids; or a Herfindahl index based on Compustat firms may not adequately measure industry concentration ratios, due to the omission of private firms.

\subsubsection{Benefits to the management of the acquiring firm}

The final benefit to control assumes an agency conflict at the acquirer. We proxy for agency-motivated acquisitions by identifying acquirer firms with both low growth options (Q low) and high free cash flow (FCF high), as in Lang, Stulz, and Walkling (1991). Acquirer free cash flow is estimated following Lehn and Poulsen (1989) as the firm's operating income before 
depreciation minus interest expense, taxes, preferred dividends, and common dividends. This value is normalized by total assets.

Results in column 3 show a majority acquisition is more likely when the acquirer has both low growth options and high free cash flow, as indicated by the negative coefficient on the interaction term. This result suggests that acquirer managerial objectives can drive the mode of acquisition.

\subsubsection{Analysis of the mode of acquisition}

In column 4, we include all significant proxies associated with motivations for majority acquisitions, as well as controls for target and acquirer market capitalizations. Earlier results are robust. Furthermore, in column 5, we include all significant proxies associated with motivations for minority or majority acquisitions together and find results similar to those reported in earlier regressions, with one exception. Column 5 reports an insignificant coefficient on MB difference $(\mathrm{p}=0.12)$. This insignificant finding may be driven by collinearity given the significant and negative correlation between $\mathrm{MB}$ difference and same industry. ${ }^{8}$ In sum, we find minority acquisitions are more likely when it is important to maintain target managerial incentives, help alleviate the target's financing constraints, further assess the desirability of a majority acquisition, and avoid diluting EPS at the acquirer. We find majority control acquisitions are more likely when larger production efficiency gains are expected and the acquirer has large free cash flow and low growth options.

The economic magnitudes of the relations identified above are substantial. Using the coefficients in column 5 and following the procedure in Fee, Hadlock, and Thomas (2006), we

\footnotetext{
${ }^{8}$ In an unreported regression, MB difference is significant when column 5 is re-estimated without the variable same industry.
} 
estimate the probability of a minority acquisition while separately varying each scalar variable from the $10^{\text {th }}$ to the $90^{\text {th }}$ percentile of the sample distribution and each binary variable from 0 to 1 . All other variables are kept constant at sample means.

If the acquirer and target share an industry, the estimated probability of a minority acquisition decreases from $8.97 \%$ to $3.82 \%$. Likewise, an acquirer with high free cash flow and low growth options decreases the estimated probability of a minority acquisition from $3.82 \%$ to 2.98\%. The corresponding estimates, associated with increasing relative size at firms with low accounting pay sensitivity, are $4.84 \%$ to $1.62 \%$. A high patent acquirer increases the estimated probability of a minority acquisition from $3.82 \%$ to $7.56 \%$. A target with a negative FCF increases the probability of a minority acquisition from $3.82 \%$ to $6.37 \%$. The corresponding estimates, associated with not having a 5\% blockholder at a firm with low analyst coverage, increase the probability of a minority acquisition from $3.82 \%$ to $7.86 \%$. Increasing industry volatility increases the probability of a minority acquisition from $2.51 \%$ to $7.53 \%$. Finally, an expected dilution to the EPS at the acquirer increases the probability of a minority acquisition from $2.08 \%$ to $3.82 \%$.

\subsection{Robustness Tests}

In this section, we explore two additional sets of robustness tests related to the target managerial incentive hypothesis. According to the hypothesis, relative size will be a weaker predictor of the acquisition decision if stock market returns and accounting variables contain more similar information, given the loss of the stock market signal will be less costly in such cases. We proxy for information overlap by the relative importance of growth options, which can only be reflected in stock prices, and earnings informativeness or the ability of accounting 
information to predict contemporaneous stock returns. The second set of tests explores the relation between relative size and the mode of acquisition at private targets. Following a majority acquisition at a private target, there will be no delisting of the target's stock price and, thus, no expectation that information loss will depend on the relative size of the target.

\subsubsection{Public firm evidence}

Growth options are proxied with a binary variable, target MB low, which assumes a value of 1 if the target firm's market-to-book ratio is below the sample median. Column 1 of Table 7 reports a positive and significant coefficient for target MB low interacted with relative size. The results show that when growth options are low, the impact of relative size on the mode of acquisition is not economically meaningful, as captured by the sum of the coefficients on relative size and the interaction term.

Earnings informativeness is estimated following the methodology in Francis and Schipper (1999) and based on earlier arguments in Lev (1989). For each target firm, we estimate the R-squared from the following regression on the three years of quarterly data that immediately precede the acquisition announcement:

$$
\mathrm{R}_{\mathrm{j}, \mathrm{t}}=\beta_{0, \mathrm{j}}+\beta_{1, \mathrm{j}} \Delta \mathrm{EARN}_{\mathrm{j}, \mathrm{t}}+\beta_{2, \mathrm{j}} \mathrm{EARN}_{\mathrm{j}, \mathrm{t}}+\varepsilon_{\mathrm{j}, \mathrm{t}}
$$

Where $R_{j, t}$ is firm $j$ 's market adjusted returns over the 3-month period that coincides with the timing of the firm's quarterly earnings; $\triangle E A R N_{j, t}$ is firm $\mathrm{j}$ 's operating income before depreciation at time $\mathrm{t}$ minus its operating income before depreciation at time $\mathrm{t}-1$, deflated by the market value of equity from $\mathrm{t}-1$; and $\mathrm{EARN}_{\mathrm{j}, \mathrm{t}}$ is firm $\mathrm{j}$ 's operating income before depreciation at time $\mathrm{t}$, deflated by the market value of equity from $\mathrm{t}-1$. The $\mathrm{R}$-squared values from these 
regressions will reflect the extent to which earnings data summarize the same information that affects stock market returns.

Earnings informativeness high is an indicator variable that takes the value of 1 if the estimated R-squared is above the sample median. As predicted, we observe a weaker relation between relative size and the mode of acquisition when earnings are more informative, as reported in column 2. These results are consistent with the target managerial incentive hypothesis.

\subsubsection{Public and private firm evidence}

The sample in columns 3 and 4 is expanded to also include acquisitions involving private targets. SDC identifies 16,158 acquisitions involving U.S. public acquirers and U.S. private targets between 1994 and 2006, where sufficient information is available to classify each observation as either a minority or majority acquisition, and the acquirer can be matched to CRSP. Information on transaction size, essential for the following tests, is available for 6,882 of these private targets observations. To this sample, we also add 201 acquisitions by U.S. public acquirers of U.S. public targets for which we have sufficient data to be included in the following tests but which were excluded from the earlier sample of public targets because of an inability to match the target to CRSP. As in earlier tables, the dependent variable assumes a value of 1 if the acquisition is for minority ownership and a value of 0 if majority control is attained.

For this public-private target sample, we estimate the implied target market capitalization by dividing the percentage of target shares acquired into an adjusted transaction price. Using an unadjusted transaction price to determine firm size is problematic, as majority acquisitions typically occur at a higher premium relative to minority acquisitions. To adjust for this bias, we increase the transaction prices of minority acquisitions by the difference in these premiums. The 
transaction value for all minority acquisitions is multiplied by 1.125 , the ratio of $(1+$ average majority acquisition premium) to $(1+$ average minority acquisition premium), where average premiums were estimated using the public target sample. Estimated relative size is a ratio of the implied market value of the target to the sum of the implied market value of the target and the market capitalization of the acquirer.

Consistent with earlier results, column 3 reports a negative coefficient on estimated relative size, indicating that relatively small public targets are more likely to be associated with minority acquisitions. However, for private targets, this relation is significantly weaker. Column 5 explores the relation between relative size and the likelihood of a minority acquisition for just the sample of private target and shows a positive, albeit insignificant, relation.

Private targets with VC backing may have a strong preference for majority control acquisitions. Thus, we also control for VC backing of target firm. To identify VC backing, we merge the data in our sample with firms that received VC funding, as identified in VentureXpert. We are able to identify VC backing for 978 target firms. Target firms with previous VC funding are more likely to be acquired in a majority acquisition.

Officer (2007) argues that private targets become more liquidity constrained as yield spreads increase. We consequently control for the yield spread, estimated as the average difference in the Baa corporate and Treasury yields over the preceding twelve-month window, and interact it with an indicator variable for private targets. Column 3 reports a more positive relation between the yield spread and minority acquisitions for deals involving private targets, relative to public targets. These results could indicate that minority acquisitions of private targets are a means to provide liquidity at a time of need. However, the relation between yield spread 
and minority acquisition is not statistically significant, when considering just the sample of private target acquisitions, as reported in column 5.

Column 4 includes acquirer fixed effects, thus limiting the sample to acquirers that engage in both minority and majority acquisitions over the sample time period. ${ }^{9}$ With this sample of repeat acquirers, we can test whether possible differences in the set of acquirers that engage in minority, rather than majority, acquisitions drive the results. We find no such evidence.

In sum, these results support the hypothesis that firms anticipate costs associated with diluting target managerial incentives and structure their acquisitions to minimize such costs when necessary.

\section{Conclusion}

Firms weigh costs to acquiring control against the anticipated benefits when deciding between a minority and majority acquisition. Majority acquisitions are more frequent when greater value gains are expected from the ability to maximize joint production. Majority acquisitions are also more frequent when acquiring firms have both large free cash flows and low growth options, suggesting agency motivations are important drivers for some managers to seek majority control. On the other hand, majority acquisitions are less common when combining the internal capital markets of the target and acquirer will be costly and when a merger is expected to lower the EPS at the acquirer.

The key insight provided in this paper is the importance of costs associated with the dilution to target managerial incentives following a majority acquisition in selecting the mode of acquisition. Evidence that firms are willing to forgo benefits to control to preserve target

\footnotetext{
${ }^{9} \mathrm{We}$ are unable to estimate the coefficient for VC-funded after limiting the sample to acquirers with both minority and majority acquisitions.
} 
incentives speaks to the value of these incentives. Furthermore, these results present new evidence of agency considerations in ownership decisions.

We also document a number of additional benefits to minority acquisitions. A minority acquisition can act to certify the target and provide direct financing. Finally, we show that some minority acquisitions are motivated to learn more about the target and expected synergies from a merger before committing to the larger investment required in a majority acquisition. 


\section{References}

Aghion, P., and J. Tirole. 1994. The management of innovation. Quarterly Journal of Economics 109:1185-1209.

Allen, J., and G. Phillips. 2000. Corporate equity ownership, strategic alliances, and product market relationships. Journal of Finance 55:2791-2815.

Bradley, M., Desai, A., and E. Kim. 1988. Synergistic gains from corporate acquisitions and their division between the stockholders of target and acquiring firms. Journal of Financial Economics 21:3-40.

Celikyurt, U., Sevilir, M., and A. Shivdasani. 2010. Going public to acquire? The acquisition motive in IPOs. Journal of Financial Economics 96:345-363.

Dasgupta, S., and Z. Tao. 2000. Bargaining, bonding, and partial ownership. International Economic Review 41:609-635.

D’Souza, J., and J. Jacob. 2000. Why firms issue targeted stock. Journal of Financial Economics 56:459-483.

Fee, C., Hadlock, C., and S. Thomas. 2006. Corporate equity ownership and the governance of product market relationships. Journal of Finance 61:1217-1251.

Fee, C., and S. Thomas. 2004. Sources of gains in horizontal mergers: Evidence from customer, supplier, and rival firms. Journal of Financial Economics 74:423-460.

Field, L., and J. Karpoff. 2002. Takeover defenses of IPO firms. Journal of Finance 57:18571889.

Filson, D., and R. Morales. 2006. Equity links and information acquisition in biotechnology alliances. Journal of Economic Behavior \& Organization 59:1-28.

Francis, J., and K. Schipper. 1999. Have financial statements lost their relevance? Journal of Accounting Research 37:319-352.

Gabaix, X., and A. Landier. 2008. Why has CEO pay increased so much? Quarterly Journal of Economics 123:49-100.

Gilo, D. 2000. The anticompetitive effect of passive investment. Michigan Law Review 99:1-47.

Grossman, S., and O. Hart. 1986. The costs and benefits of ownership: A theory of lateral and vertical integration. Journal of Political Economy 94:691-719.

Hadlock, C., and J. Pierce. 2010. New evidence on measuring financial constraints: Moving beyond the KZ index. Review of Financial Studies 23:1909-1940. 
Hart, O. 1995. Firms, Contracts and Financial Structure. Oxford, England: Oxford University Press.

Hart, O., and J. Moore. 1990. Property rights and the nature of the firm. Journal of Political Economy 98:1119-1158.

Hertzel, M., and R. Smith. 1993. Market discounts and shareholder gains for placing equity privately. Journal of Finance 48:459-485

Higgins, M., and D. Rodriquez. 2006. The outsourcing of R\&D through acquisitions in the pharmaceutical industry. Journal of Financial Economics 80:351-383.

Holmstrom, B., and J. Tirole. 1989. The theory of the firm. Chapter 2 of The Handbook of Industrial Organization, R. Schmalensee and R. Willig (eds.), Amsterdam: North-Holland.

Holmstrom, B., and J. Tirole. 1993. Market liquidity and performance monitoring. Journal of Political Economy 101:678-709.

Jensen, M. 1986. Agency costs of free cash flow, corporate finance and takeovers. American Economic Review 76:323-329.

Jensen, M., and W. Meckling. 1976. Theory of the firm: Managerial behavior, agency costs, and ownership structure. Journal of Financial Economics 3:305-360.

Kang, J. and J. Kim. 2008. The geography of block acquisitions. The Journal of Finance 63: 2817-2858.

Klein, B., R. Crawford, and A. Alchian. 1978. Vertical integration, appropriable rents, and the competitive contracting process. Journal of Law and Economics 21:297-326.

Kim, W. 2012. Investor protection and the mode of acquisition: Implications for ownership dilution and formation of pyramids. Financial Management 41:55-93.

Kim, E., and V. Singal. 1993. Mergers and market power: Evidence from the airline industry. The American Economic Review 83:549-569.

Kim, W., and M. Weisbach. 2008. Motivations for public equity offers: An international perspective. Journal of Financial Economics 87:281-307.

Lang, L., Stulz, R., and R. Walkling. 1991. A test of the free cash flow hypothesis: The case of bidder returns. Journal of Financial Economics 29:315-335.

Lehn, K., and A. Poulsen. 1989. Free cash flow and stockholder gains in going private transactions. Journal of Finance 44:771-787. 
Lev, B. 1989. On the usefulness of earning and earnings research: Lessons and directions from two decades of empirical research. Journal of Accounting Research 27:153-92.

Liao, R. 2011. What drives corporate block acquisitions? The case for financial constraints. Working paper.

Loughran, T., and J. Ritter. 2004. Why has IPO underpricing changed over time? Financial Management 33:5-37.

Maksimovic, V., and G. Phillips. 2001. The market for corporate assets: Who engages in mergers and asset sales, and are there efficiency gains? Journal of Finance 56:2019-2065.

Murphy, K. 1985. Corporate performance and managerial remuneration: An empirical analysis. Journal of Accounting and Economics 7:11-42.

Officer, M. 2007. The price of corporate liquidity: Acquisition discounts for unlisted targets. Journal of Financial Economics 83:571-598.

Rajan, R., Servaes, H., and L. Zingales. 2000. The cost of diversity: The diversification discount and inefficient investment. Journal of Finance 55:35-80.

Seru, A. 2011. Firm boundaries matter: Evidence from conglomerates and R\&D activity. Journal of Financial Economics, forthcoming.

Shahrur, H. 2005. Industry structure and horizontal takeovers: Analysis of wealth effects on rivals, suppliers, and corporate customers. Journal of Financial Economics 76:61-98.

Shleifer, A. and R. Vishny. 1986. Large shareholders and corporate control. The Journal of Political Economy 94:461-488.

Wruck, K. 1989. Equity ownership concentration and firm value. Journal of Financial Economics 23:3-28. 
Table 1. Summary of key motivations for minority and majority acquisitions. This table details the proxies associated with each key motivation (column 2) and the predicted correlation between the proxy and the likelihood of a minority acquisition (column 3).

\begin{tabular}{|l|l|l|}
\hline Motivation & Proxy & $\begin{array}{l}\text { Predicted correlation between } \\
\text { proxy and minority acquisition } \\
\text { likelihood }\end{array}$ \\
\hline $\begin{array}{l}\text { Target managerial } \\
\text { equity incentives }\end{array}$ & Relative size of the target & - \\
\hline $\begin{array}{l}\text { Relationship-specific } \\
\text { investment incentives }\end{array}$ & Acquirer patent count & + \\
\hline $\begin{array}{l}\text { Acquirer financing } \\
\text { constraints }\end{array}$ & Relative size of the target & + \\
\hline Target financing & Financially constrained target & + \\
\cline { 2 - 4 } & $\begin{array}{l}\text { Target has limited analyst coverage } \\
\text { and does not have a pre-existing } \\
\text { blockholder }\end{array}$ & + \\
\hline Real options & Return volatility in target's industry & + \\
\hline Internal capital markets & $\begin{array}{l}\text { ifference in growth options } \\
\text { between acquirer and target } \\
\text { industries }\end{array}$ & + \\
\hline Earnings dilution & $\begin{array}{l}\text { If consolidating acquisition will } \\
\text { lower acquirer EPS }\end{array}$ & + \\
\hline $\begin{array}{l}\text { Gains associated with } \\
\text { complete integration }\end{array}$ & $\begin{array}{l}\text { Acquirer and target operate in same } \\
\text { industry }\end{array}$ & - \\
\cline { 2 - 4 } & $\begin{array}{l}\text { Herfindahl index for acquirer } \\
\text { industry }\end{array}$ & - \\
\hline $\begin{array}{l}\text { Agency-motivated } \\
\text { acquisitions }\end{array}$ & $\begin{array}{l}\text { Acquirer has high free cash flow } \\
\text { and low growth options }\end{array}$ & - \\
\hline
\end{tabular}


Table 2. Firm and deal characteristics for minority and majority acquisitions between 1994 and 2006 by and of U.S. public firms

All variables are winsorized at the $1 \%$ level. Market capitalization is estimated 28 days before the deal announcement. All accounting variables are taken from the most recent annual report, which strictly predates the acquisition announcement, and are defined as follows: total assets (Compustat data 6); R \& D intensity (Compustat data 46 / Compustat data 6; this variable is set to 0 if total assets are reported for a firm in the same year but no record is reported for $\mathrm{R} \& \mathrm{D}$ expenditures); book to market (Compustat data 60 / market capitalization); and return on assets (Compustat data 13 / total assets). Relative size is the ratio of the target firm to the size of the combined firms using market capitalizations estimated 28 days before the deal was announced. Announcement returns are calculated using a market model and compounded as buy-and-hold returns over the observation window. Difference in means is calculated using a t-test. Difference in medians is calculated using a Wilcoxon rank-sum test. Significance is noted as $* * *, * *, *$ for $1 \%, 5 \%$, and $10 \%$ respectively.

\begin{tabular}{|c|c|c|c|c|c|c|c|c|}
\hline \multirow[t]{2}{*}{ Variable } & \multicolumn{3}{|c|}{ Minority Acquisition } & \multicolumn{3}{|c|}{ Majority Acquisition } & \multirow[t]{2}{*}{$\begin{array}{c}\text { Difference } \\
\text { (means) }\end{array}$} & \multirow[t]{2}{*}{$\begin{array}{l}\text { Difference } \\
\text { (medians) }\end{array}$} \\
\hline & Mean & Median & $\mathrm{N}$ & Mean & Median & $\mathrm{N}$ & & \\
\hline $\begin{array}{l}\text { Percentage of shares acquired in } \\
\text { transaction }(\%)\end{array}$ & 12.19 & 8.94 & 254 & 98.45 & 100.00 & 1913 & $* * *$ & $* * *$ \\
\hline $\begin{array}{l}\text { Percentage of shares owned after } \\
\text { transaction }(\%)\end{array}$ & 14.85 & 10.40 & 255 & 99.11 & 100.00 & 1913 & $* * *$ & $* * *$ \\
\hline $\begin{array}{l}\text { Acquirer market capitalization } \\
\text { (millions, } 2006 \$ \text { ) }\end{array}$ & $42,582.72$ & $7,775.76$ & 255 & $14,772.95$ & $1,786.23$ & 1913 & $* * *$ & $* * *$ \\
\hline $\begin{array}{l}\text { Acquirer total assets (millions, } \\
2006 \$ \text { ) }\end{array}$ & $15,287.61$ & $3,428.08$ & 241 & $6,812.80$ & $1,209.74$ & 1832 & $* * *$ & $* * *$ \\
\hline Acquirer R\&D intensity (\%) & 5.76 & 2.48 & 241 & 5.03 & 1.50 & 1832 & $* * *$ & $* * *$ \\
\hline Acquirer book to market & 0.34 & 0.26 & 237 & 0.40 & 0.32 & 1794 & $* *$ & $* * *$ \\
\hline Acquirer return on assets (\%) & 13.18 & 13.67 & 240 & 11.88 & 14.29 & 1819 & & \\
\hline $\begin{array}{l}\text { Target market capitalization } \\
\text { (millions, } 2006 \$ \text { ) }\end{array}$ & $1,271.66$ & 168.34 & 255 & $1,084.15$ & 176.06 & 1913 & & \\
\hline $\begin{array}{l}\text { Target total assets (millions, } \\
2006 \$ \text { ) }\end{array}$ & $1,073.98$ & 102.52 & 241 & 979.95 & 159.86 & 1816 & & $* * *$ \\
\hline Target R\&D intensity (\%) & 12.79 & 3.94 & 241 & 7.58 & 0.86 & 1816 & $* * *$ & $* * *$ \\
\hline Target book to market & 0.44 & 0.31 & 232 & 0.58 & 0.44 & 1778 & $* * *$ & $* * *$ \\
\hline Target return on assets (\%) & -12.01 & 1.28 & 237 & 3.67 & 10.68 & 1801 & $* * *$ & $* * *$ \\
\hline Relative size & 0.11 & 0.03 & 255 & 0.18 & 0.12 & 1913 & $* * *$ & $* * *$ \\
\hline $\begin{array}{l}\text { Acquirer market-adjusted } \\
\text { returns: 3-day window }(-1: 1)(\%)\end{array}$ & 0.12 & 0.00 & 243 & -0.51 & -0.32 & 1789 & $*$ & $* * *$ \\
\hline $\begin{array}{l}\text { Target market-adjusted returns: } \\
\text { 3-day window }(-1: 1)(\%)\end{array}$ & 3.52 & 2.70 & 243 & 7.25 & 5.92 & 1784 & $* * *$ & $* * *$ \\
\hline $\begin{array}{l}\text { Joint market-adjusted returns: } 3 \text { - } \\
\text { day window }(-1: 1)(\%)\end{array}$ & 0.32 & 0.17 & 239 & 0.46 & 0.34 & 1768 & & \\
\hline
\end{tabular}


Table 3. Industry distribution of minority and majority acquisitions between 1994 and 2006 by and of U.S. public firms

\begin{tabular}{|c|c|c|c|c|c|}
\hline \multicolumn{2}{|l|}{ SIC codes } & \multicolumn{2}{|c|}{ Target industry } & \multicolumn{2}{|c|}{ Acquirer industry } \\
\hline & & Minority & Majority & Minority & Majority \\
\hline $0000-999$ & Food products & $0.39 \%$ & $0.16 \%$ & $0.00 \%$ & $0.16 \%$ \\
\hline $1000-1999$ & Mining and construction & $3.92 \%$ & $5.91 \%$ & $2.75 \%$ & $6.06 \%$ \\
\hline $2000-2999$ & Consumer products & $20.00 \%$ & $12.02 \%$ & $21.18 \%$ & $13.90 \%$ \\
\hline $3000-3999$ & Manufacturing & $26.67 \%$ & $32.51 \%$ & $30.20 \%$ & $33.46 \%$ \\
\hline $4000-4999$ & Utilities and transportation & $12.55 \%$ & $9.30 \%$ & $17.25 \%$ & $10.51 \%$ \\
\hline $5000-5999$ & Wholesale, retail, and some services & $5.88 \%$ & $8.57 \%$ & $4.71 \%$ & $8.31 \%$ \\
\hline $6000-6999$ & Financial services & $2.75 \%$ & $1.15 \%$ & $0.00 \%$ & $0.00 \%$ \\
\hline $7000-7999$ & Personal \& business services & $24.71 \%$ & $23.99 \%$ & $21.18 \%$ & $22.27 \%$ \\
\hline $8000-8999$ & Miscellaneous & $3.14 \%$ & $6.33 \%$ & $2.75 \%$ & $5.28 \%$ \\
\hline $9000-9999$ & Miscellaneous & $0.00 \%$ & $0.05 \%$ & $0.00 \%$ & $0.05 \%$ \\
\hline
\end{tabular}




\section{Table 4. The role of target managerial incentives in the acquisition decision}

The sample includes minority and majority acquisitions announced between 1994 and 2006 by and of U.S. public firms. Column 7 excludes observations where the acquiring firm reports sales in multiple segments and the target CEO has insignificant ownership. The dependent variable is 1 if a minority stake was acquired and a 0 if a majority stake was acquired. Relative size is the ratio of the target firm to the size of the combined firms, using market capitalizations estimated 28 days before the deal was announced. Market capitalizations are transformed by the $\log$ and standardized in 2006 \$. FINCON is an indicator variable that is 1 if the firm's founding date is in the lowest sample quartile and at least 5 years have passed since the firm's IPO, and 0 otherwise. CEO accounting pay sensitivity high is an indicator variable that is 1 if the target firm is in an industry in which the correlation between CEO pay and accounting performance is above the sample median, 0 otherwise. Patents are from the NBER Patent Data Project. High patent acquirer is an indicator variable that is 1 if the acquirer is in the top quartile of the sample distribution ( $\geq 10$ patents), 0 otherwise. High patent target is an indicator variable that is 1 if the target is in the $80^{\text {th }}$ percentile ( $\geq 1$ patent), 0 otherwise. Firms are assumed to have no patents if unmatched to the patent data sample. Target CEO < 1\% is a dummy variable that is 1 if the target CEO has beneficial ownership of less than $1 \%$ of the target firm, 0 otherwise. Single segment is a dummy variable that is 1 if the firm does not report sales in multiple business segments, 0 otherwise. Industry (target and acquirer 1-digit SIC code) and year fixed effects are included. Coefficients are reported with standard errors in parentheses. Standard errors are robust and corrected for clustering in acquirer. Significance is noted as ***,**, * for $1 \%, 5 \%$, and $10 \%$ respectively.

\begin{tabular}{|c|c|c|c|c|c|c|c|}
\hline & $\begin{array}{c}\text { Full } \\
\text { Sample }\end{array}$ & $\begin{array}{c}\text { Full } \\
\text { Sample }\end{array}$ & $\begin{array}{c}\text { Full } \\
\text { Sample }\end{array}$ & $\begin{array}{c}\text { Full } \\
\text { Sample }\end{array}$ & $\begin{array}{c}\text { Full } \\
\text { Sample }\end{array}$ & $\begin{array}{c}\text { Full } \\
\text { Sample }\end{array}$ & $\begin{array}{c}\text { Single Segment } \\
\text { Acquirers/Target } \\
\text { CEO }>1 \%\end{array}$ \\
\hline & 1 & 2 & 3 & 4 & 5 & 6 & 7 \\
\hline Relative size & $\begin{array}{l}-3.26 \\
(0.88)^{* * *}\end{array}$ & & $\begin{array}{l}-3.47 \\
(0.92) * * *\end{array}$ & $\begin{array}{l}-4.82 \\
(1.47)^{* * * *}\end{array}$ & & & \\
\hline $\begin{array}{l}\text { Target market } \\
\text { capitalization }\end{array}$ & & $\begin{array}{l}-0.28 \\
(0.05)^{* * *}\end{array}$ & & & & & $\begin{array}{l}-0.23 \\
(0.08) * * *\end{array}$ \\
\hline $\begin{array}{l}\text { Acquirer market } \\
\text { capitalization }\end{array}$ & & $\begin{array}{l}0.39 \\
(0.06)^{* * * *}\end{array}$ & & & & & $\begin{array}{l}0.39 \\
(0.08)^{* * *}\end{array}$ \\
\hline Acquirer & & & -0.78 & & & & \\
\hline FINCON & & & $(0.94)$ & & & & \\
\hline Acquirer & & & 4.56 & & & & \\
\hline $\begin{array}{l}\text { FINCON * } \\
\text { relative size }\end{array}$ & & & $(2.57)^{*}$ & & & & \\
\hline $\begin{array}{l}\text { CEO acc pay } \\
\text { sensitivity high }\end{array}$ & & & & $\begin{array}{l}-0.61 \\
(0.25)^{* *}\end{array}$ & & & \\
\hline $\begin{array}{l}\text { CEO acc pay } \\
\text { sensitivity high * } \\
\text { relative size }\end{array}$ & & & & $\begin{array}{l}3.07 \\
(1.72)^{*}\end{array}$ & & & \\
\hline $\begin{array}{l}\text { High patent } \\
\text { acquirer }\end{array}$ & & & & & $\begin{array}{l}0.82 \\
(0.27) * * *\end{array}$ & $\begin{array}{c}0.39 \\
(0.35)\end{array}$ & $\begin{array}{l}0.54 \\
(0.32)^{*}\end{array}$ \\
\hline $\begin{array}{l}\text { High patent } \\
\text { target }\end{array}$ & & & & & $\begin{array}{l}-0.35 \\
(0.22)\end{array}$ & & \\
\hline Target CEO < & & & & & & 0.01 & \\
\hline $1 \%$ & & & & & & $(0.23)$ & \\
\hline $\begin{array}{l}\text { High patent } \\
\text { acquirer } * \text { Target } \\
\text { CEO }<1 \%\end{array}$ & & & & & & $\begin{array}{l}-0.72 \\
(0.41)^{*}\end{array}$ & \\
\hline Single segment & & & & & & $\begin{array}{l}-0.11 \\
(0.26)\end{array}$ & \\
\hline $\begin{array}{l}\text { High patent } \\
\text { acquirer * single } \\
\text { segment }\end{array}$ & & & & & & $\begin{array}{l}0.93 \\
(0.50)^{*}\end{array}$ & \\
\hline R-squared & 0.09 & 0.09 & 0.10 & 0.10 & 0.08 & 0.09 & 0.18 \\
\hline $\mathrm{N}$ & 2166 & 2166 & 2166 & 2091 & 2166 & 1772 & 1032 \\
\hline
\end{tabular}




\section{Table 5. The role of other benefits to minority stakes in the acquisition decision}

The sample includes minority and majority acquisitions announced between 1994 and 2006 by and of U.S. public firms. The dependent variable is 1 if a minority stake was acquired and 0 if a majority stake was acquired. FCF negative is an indicator variable which is 1 if the sum of the firm's income before extraordinary items plus depreciation and amortization less capital expenditures is less than zero, 0 otherwise. Target FINCON is an indicator variable which is 1 if the firm's founding date is in the lowest sample quartile and at least 5 years have passed since the firm's IPO, 0 otherwise. No 5\% block is an indicator variable which is 1 if no institutional owner has a $5 \%$ or greater position in the firm prior to the acquisition announcement, 0 otherwise. Target analyst coverage low is an indicator variable which is 1 if the firm has a count of analyst coverage below the sample median, 0 otherwise. Same state is an indicator variable which is 1 if the target and firm are located in the same state, 0 otherwise. Industry volatility is estimated as the average variance in monthly stock returns, estimated over the year prior to the acquisition announcement, for the target firm's industry. MB difference is the absolute value of the difference between the industry median market to book ratios for the target and acquirer, normalized by the market to book ratio of the acquirer. EPS dilutive is an indicator variable which is 1 if the consolidated firm would have lower EPS as compared to the stand-alone acquirer, 0 otherwise. Market capitalizations are transformed by the log and standardized in 2006 \$. Industry (target and acquirer 1-digit SIC code) and year fixed effects are included. Coefficients are reported with standard errors in parentheses. Standard errors are robust and corrected for clustering in acquirer. Significance is noted as $* * *, * *, *$ for $1 \%, 5 \%$, and $10 \%$ respectively.

\begin{tabular}{|c|c|c|c|c|c|c|c|c|}
\hline & 1 & 2 & 3 & 4 & 5 & 6 & 7 & 8 \\
\hline $\begin{array}{l}\text { Target FCF } \\
\text { negative }\end{array}$ & $\begin{array}{l}0.89 \\
(0.17)^{* * *}\end{array}$ & & & $\begin{array}{l}0.82 \\
(0.17)^{* * *}\end{array}$ & & & & $\begin{array}{l}0.48 \\
(0.21)^{* *}\end{array}$ \\
\hline Target & & 0.63 & & & & & & \\
\hline FINCON & & $(0.33)^{*}$ & & & & & & \\
\hline No $5 \%$ & & & 0.64 & 0.14 & & & & 0.22 \\
\hline Block & & & $(0.14)^{* * *}$ & $(0.29)$ & & & & (0.30) \\
\hline Target & & & & 0.04 & & & & 0.25 \\
\hline $\begin{array}{l}\text { analyst } \\
\text { coverage low }\end{array}$ & & & & $(0.22)$ & & & & $(0.29)$ \\
\hline Target & & & & 0.60 & & & & 0.73 \\
\hline analyst & & & & $(0.36)^{*}$ & & & & $(0.44)^{*}$ \\
\hline \multicolumn{9}{|l|}{ coverage low } \\
\hline \multicolumn{8}{|l|}{$*$ no $5 \%$} & block \\
\hline Same state & & & & $\begin{array}{l}-0.25 \\
(0.27)\end{array}$ & & & & \\
\hline Same state * & & & & -0.07 & & & & \\
\hline no $5 \%$ block & & & & $(0.38)$ & & & & \\
\hline Industry & & & & & 4.20 & & & 4.80 \\
\hline volatility & & & & & $(1.55)^{* * *}$ & & & $(2.30)^{* *}$ \\
\hline MB & & & & & & 0.41 & & 0.42 \\
\hline difference & & & & & & $(0.14) * * *$ & & $(0.21)^{* *}$ \\
\hline EPS dilutive & & & & & & & $\begin{array}{l}0.93 \\
(0.19) * * *\end{array}$ & $\begin{array}{l}0.49 \\
(0.21)^{* *}\end{array}$ \\
\hline Acquirer & & & & & & & & 0.31 \\
\hline market & & & & & & & & $(0.07)^{* * *}$ \\
\hline capitalization & & & & & & & & \\
\hline Target & & & & & & & & -0.03 \\
\hline market & & & & & & & & $(0.07)$ \\
\hline capitalization & & & & & & & & \\
\hline R-squared & 0.09 & 0.07 & 0.08 & 0.11 & 0.04 & 0.07 & 0.10 & 0.17 \\
\hline $\mathrm{N}$ & 2005 & 2166 & 2166 & 2005 & 2160 & 1915 & 1799 & 1537 \\
\hline
\end{tabular}




\section{Table 6. The role of benefits to majority control in the acquisition decision}

The sample includes minority and majority acquisitions announced between 1994 and 2006 by and of U.S. public firms. The dependent variable is 1 if a minority stake was acquired and 0 if a majority stake was acquired. Same industry is an indicator variable which is 1 if the target and acquirer operate in the same 3-digit SIC code, 0 otherwise. FCF high (Q low) is an indicator variable which is 1 if the firm's FCF (Q) is in the top (bottom) half of the sample distribution, 0 otherwise. Q is market capitalization divided by book equity. Market capitalizations are transformed by the log and standardized in 2006 . Relative size is the ratio of the target firm to the size of the combined firms using market capitalizations estimated 28 days before the deal was announced. CEO accounting pay sensitivity high is an indicator variable which is 1 if the target firm is in an industry in which the correlation between CEO pay and accounting price performance is above the sample median, 0 otherwise. High patent acquirer is an indicator variable which is 1 if the firm has patents in the top quartile of the sample distribution, 0 otherwise. FCF negative is an indicator variable which is 1 if the sum of the firm's income before extraordinary items plus depreciation and amortization less capital expenditures is less than zero, 0 otherwise. No 5\% block is an indicator variable which is 1 if no institutional owner has a $5 \%$ or greater position in the firm prior to the acquisition announcement, 0 otherwise. Target analyst coverage low is an indicator variable which is 1 if the firm has a count of analyst coverage below the sample median, 0 otherwise. Industry volatility is estimated as the average variance in monthly stock returns, estimated over the year prior to the acquisition announcement, for the target firm's industry. MB difference is the absolute value of the difference between the industry median market-to-book ratios for the target and acquirer, normalized by the marketto-book ratio of the acquirer. EPS dilutive is an indicator variable which is 1 if the consolidated firm would have lower EPS as compared to the stand-alone acquirer, 0 otherwise. Industry (target and acquirer 1-digit SIC code) and year fixed effects are included. Coefficients are reported with standard errors in parentheses. Standard errors are robust and corrected for clustering in acquirer. Significance is noted as $* * *, * *, *$ for $1 \%, 5 \%$, and $10 \%$ respectively. 


\begin{tabular}{|c|c|c|c|c|c|}
\hline & 1 & 2 & 3 & 4 & 5 \\
\hline Same industry & $\begin{array}{l}-0.75 \\
(0.15)^{* * *}\end{array}$ & & & $\begin{array}{l}-0.73 \\
(0.17)^{* * *}\end{array}$ & $\begin{array}{l}-0.91 \\
(0.22)^{* * *}\end{array}$ \\
\hline Acquirer industry Herfindahl index & & $\begin{array}{l}-0.24 \\
(0.91)\end{array}$ & & & \\
\hline Acquirer Q low & & & $\begin{array}{l}0.13 \\
(0.19)\end{array}$ & $\begin{array}{l}0.62 \\
(0.22)^{* * *}\end{array}$ & $\begin{array}{l}0.74 \\
(0.24)^{* * *}\end{array}$ \\
\hline Acquirer FCF high & & & $\begin{array}{l}0.63 \\
(0.26)^{* *}\end{array}$ & $\begin{array}{l}0.95 \\
(0.25)^{* * *}\end{array}$ & $\begin{array}{l}1.08 \\
(0.33)^{* * *}\end{array}$ \\
\hline Acquirer $\mathrm{Q}$ low * acquirer FCF high & & & $\begin{array}{l}-1.25 \\
(0.45) * * *\end{array}$ & $\begin{array}{l}-1.40 \\
(0.41)^{* * *}\end{array}$ & $\begin{array}{l}-2.07 \\
(0.54) * * *\end{array}$ \\
\hline Acquirer market capitalization & & & & $\begin{array}{l}0.37 \\
(0.06)^{* * *}\end{array}$ & \\
\hline Target market capitalization & & & & $\begin{array}{l}-0.27 \\
(0.05)^{* * *}\end{array}$ & \\
\hline Relative size & & & & & $\begin{array}{l}-2.66 \\
(1.40)^{*}\end{array}$ \\
\hline CEO accounting pay sensitivity high & & & & & $\begin{array}{l}-0.13 \\
(0.29)\end{array}$ \\
\hline $\begin{array}{l}\text { CEO accounting pay sensitivity high } * \\
\text { relative size }\end{array}$ & & & & & $\begin{array}{l}2.87 \\
(1.68)^{*}\end{array}$ \\
\hline High patent acquirer & & & & & $\begin{array}{l}0.72 \\
(0.30) * *\end{array}$ \\
\hline Target FCF negative & & & & & $\begin{array}{l}0.54 \\
(0.23)^{* *}\end{array}$ \\
\hline No $5 \%$ block & & & & & $\begin{array}{c}0.14 \\
(0.32)\end{array}$ \\
\hline Target analyst coverage low & & & & & $\begin{array}{l}-0.18 \\
(0.29)\end{array}$ \\
\hline Target analyst coverage low $*$ no $5 \%$ block & & & & & $\begin{array}{l}0.81 \\
(0.45)^{*}\end{array}$ \\
\hline Industry volatility & & & & & $\begin{array}{l}7.20 \\
(2.49)^{* * *}\end{array}$ \\
\hline MB difference & & & & & $\begin{array}{l}0.41 \\
(0.26)\end{array}$ \\
\hline EPS dilutive & & & & & $\begin{array}{l}0.62 \\
(0.21)^{* * *}\end{array}$ \\
\hline R-squared & 0.08 & 0.06 & 0.08 & 0.16 & 0.19 \\
\hline $\mathrm{N}$ & 2166 & 1969 & 2029 & 2029 & 1506 \\
\hline
\end{tabular}




\section{Table 7. Robustness tests}

The sample in columns 1 and 2 includes minority and majority acquisitions announced between 1994 and 2006 by and of U.S. public firms. The sample in columns 3 and 4 includes minority and majority acquisitions of U.S. public or private targets by U.S. public firms. The sample in column 5 includes minority and majority acquisitions of U.S. private targets by U.S. public firms. The dependent variable is 1 if a minority stake was acquired and 0 if a majority stake was acquired. Relative size is the ratio of the target firm to the size of the combined firms using market capitalizations estimated 28 days before the deal was announced. MB low is an indicator variable which is 1 if the firm's market-to-book ratio is in the bottom half of the sample distribution, 0 otherwise. Earnings informativeness is estimated as the R-squared from regressing market adjusted returns on contemporaneous earnings, following the methodology in Francis and Schipper (1999). Earnings informativeness high is an indicator variable which is 1 if the firm has a value above the sample median, 0 otherwise. Estimated relative size is a ratio of the implied market value of the target to the sum of the implied market value of the target and the market capitalization of the acquirer. The implied target market value is calculated as the adjusted transaction price divided by the percentage of the firm acquired. The transaction price for minority acquisitions is adjusted by the ratio 1.53/1.36 to reflect the difference in average premiums. VC-backed is an indicator variable which is 1 if the target received venture capital funding prior to the acquisition announcement, 0 otherwise. Baa-Treasury spread is the average difference over the last year between the yield on Baa-rated bonds and Treasury bonds. Acquirer and target industry and year fixed effects are included in columns 1-2. Target industry fixed effects are included in columns 3-5. Coefficients are reported with standard errors in parentheses. Standard errors are robust and corrected for clustering in acquirer. Significance is noted as $* * *, * *, *$ for $1 \%, 5 \%$, and $10 \%$ respectively.

\begin{tabular}{|c|c|c|c|c|c|}
\hline & \multicolumn{2}{|c|}{$\begin{array}{l}\text { Public Acquirer, Public } \\
\text { Target }\end{array}$} & \multicolumn{2}{|c|}{$\begin{array}{c}\text { Public Acquirer, Public or } \\
\text { Private Target }\end{array}$} & \multirow{2}{*}{$\begin{array}{l}\text { Public Acquirer, } \\
\text { Private Target } \\
5\end{array}$} \\
\hline & 1 & 2 & 3 & 4 & \\
\hline Relative Size & $\begin{array}{l}-4.91 \\
(1.35) * * *\end{array}$ & $\begin{array}{l}-4.58 \\
(1.56) * * *\end{array}$ & & & \\
\hline Target MB low & $\begin{array}{l}-1.02 \\
(0.25) * * *\end{array}$ & & & & \\
\hline $\begin{array}{l}\text { Target MB low * relative } \\
\text { size }\end{array}$ & $\begin{array}{l}4.21 \\
(1.61)^{* * *}\end{array}$ & & & & \\
\hline $\begin{array}{l}\text { Earnings informativeness } \\
\text { high }\end{array}$ & & $\begin{array}{l}-0.75 \\
(0.26) * * *\end{array}$ & & & \\
\hline $\begin{array}{l}\text { Earnings informativeness } \\
\text { high * relative size }\end{array}$ & & $\begin{array}{l}4.00 \\
(1.74)^{* * *}\end{array}$ & & & \\
\hline Private target & & & $\begin{array}{l}-4.17 \\
(0.54) * * *\end{array}$ & $\begin{array}{l}-2.96 \\
(1.00) * * *\end{array}$ & \\
\hline Estimated relative size & & & $\begin{array}{l}-3.67 \\
(0.71)^{* * *}\end{array}$ & $\begin{array}{l}-3.55 \\
(1.14)^{* * *}\end{array}$ & $\begin{array}{l}0.61 \\
(0.56)\end{array}$ \\
\hline $\begin{array}{l}\text { Private target } * \text { estimated } \\
\text { relative size }\end{array}$ & & & $\begin{array}{l}4.22 \\
(0.88) * * *\end{array}$ & $\begin{array}{l}3.20 \\
(1.78)^{*}\end{array}$ & \\
\hline VC-backed & & & $\begin{array}{l}-3.81 \\
(1.01)^{* * *}\end{array}$ & & \\
\hline Baa - Treasury spread & & & $\begin{array}{l}-0.81 \\
(0.17) * * *\end{array}$ & $\begin{array}{l}-0.73 \\
(0.35)^{* *}\end{array}$ & $\begin{array}{l}0.14 \\
(0.19)\end{array}$ \\
\hline $\begin{array}{l}\text { Baa - Treasury spread * } \\
\text { private target }\end{array}$ & & & $\begin{array}{l}0.95 \\
(0.24) * * *\end{array}$ & $\begin{array}{l}0.49 \\
(0.46)\end{array}$ & \\
\hline Acquirer firm fixed effects & No & No & No & Yes & No \\
\hline Pseudo R-squared & 0.11 & 0.09 & 0.14 & 0.21 & 0.01 \\
\hline $\mathrm{N}$ & 2008 & 1834 & 9241 & 1094 & 6048 \\
\hline
\end{tabular}

